\title{
ASSESSMENT OF TOURISTS ON MOJITO BASED ON ARAK BALI IN KUTA BALI
}

\author{
Setyowati Ayu Widuri \\ STP Nusa Dua Bali \\ Indonesia \\ widuriayu@gmail.com
}

\begin{abstract}
Mojito is one of the popular cocktail drinks and is very popular with domestic and foreign tourists visiting Bali because it has a refreshing taste and aroma. Mojito are generally made from Light Rum for alcohol. Rum is a fermented and distilled alcoholic beverage from molasses (sugarcane drops) or sugar cane water which is a byproduct of the sugar industry. Rum is the result of distillation from molasses (sugar cane drops) in the form of clear colored liquid, and is usually stored to experience ripening in vats made of oak or other types of wood. The largest rum producers in the world are Caribbean countries and along the Demerara River flow in Guyana, South America.
\end{abstract}

Bali also has traditional alcoholic drinks, Arak Bali. Arak Bali is one of the Alcoholic Drinks so that it can be used as an alternative for mixing Mojito drinks, because Arak Bali has almost the same content as rum both in terms of alcohol content, aroma and color. It is known that the content of Methanol, Ethanol and the taste of Arak Bali is almost the same as Light Rum.

This research was conducted to determine the rating of tourists on mojito made from Arak Bali and to be able to bring out one of the uniqueness of Bali, especially in the field of drinks, so that local Balinese geniuses have an active role in the era of globalization and to improve the economic conditions of local communities.

This research was conducted at the bar in Kuta Bali using simple quantitative descriptive analysis method, for consumer assessment indicators measured from the level of Taste of cocktail, Flavor of cocktail, Texture of Cocktail, Colour of Cocktail, Standard drink size and Standars glassware. The results of this study stated that Mojito with Arak Bali received good judgment. Which means that the Arak Bali-based Mojito that is sold at bars on Kuta beach must be promoted more to tourists.

Keywords : Arak Bali, Mojito, Cocktail, Bali

\section{INTRODUCTION}

One of the famous cocktails is Mojito. According to (https://indonesia.tripcanvas.co/id/Bali/bar-tempat0 hiburan-malam/, accessed on February 6, 2018) Mojito is one of the favorite cocktails because it has its own charm in terms of taste and aroma of fresh mint that becomes characteristic of Mojito, until now the Mojito is still one of the most sought after cocktails and sold almost in all bars. Mojito is a tropical drink drink. Tropical drinks are drinks that are dominated by fruit and sour taste. Tropical drinks are usually a mixture of sour, such as sour mix, lemon juice, and alcoholic drinks in more than one type of mixed drink.

In making Mojito drinks, one of the ingredients used is Rum. According to Katsigris and Thomas (2006: 204) Rum is an alcoholic beverage produced by fermentation and distillation from molasses (sugar cane) or sugarcane water which is a by-product of the sugar industry. The distilled rum from molasses (molasses) is a clear liquid, and is usually stored to experience ripening in barrels made from oak or other types of wood. The largest rum producers in the world are Caribbean countries and along the Demerara River in Guyana, South America. In addition, rum factories are in other countries in the world such as Australia, India, Reunion Islands. Rum consists of various types with different alcohol levels. General Light Rum is used as a cocktail mixer.

One of the light rum brands that are often used for making Cocktail is Bacardi, Bacardi is a type of light rum originating from. This drink was made by Don Facundo Bacardí Massó in 1862 and the first production was carried out in 1910 with the Spanish destination. Bacardi has an alcohol content of $65 \%$. This high alcohol content makes Bacardi more often used as a component in cocktail making although sometimes the presentation is straightforward without any mixture. Bacardi is also famous for its "flame aresster" at the tip of the bottle. The purpose of using "flame aresster" is to prevent the propagation of fire from outside into the bottle because Bacardi drinks are highly flammable. this drink had stopped selling in 1960 because all of its assets were confiscated by the Cuban government. a year later Bacardi was produced again but the time had already been transferred to Brazil. In 1965 Bacardi opened a 
branch for the distillation process in the Bahamas archipelago and continued until now (http: // yangkosongadako. Blogspot. Co. Id / 2011/10 / bacardi. Html, accessed on February 6, 2018).

In Bali also has traditional drinks containing alcohol (other spirit), namely Arak Bali. Arak is a kind of fermented liquor containing 37-60\% alcohol (ethyl alcohol) which has been known in Bali since ancient times. Arak is generally made from palm or palm trees by distillation. Arak can also be made from rice or glutinous rice through a pentapean process, then squeezed. The liquid is fermented and distilled. Arak drinks are known throughout the region in Bali, because Arak is a type of beverage that is used as a ceremonial dish (tetabuh). One of the famous Arak in Bali has a quite strong and interesting aroma character. When brought close to the nose, a distinctive soft aroma is present. (https://aditaroepratjeka.wordpress.com/2011/06/03/o ra-et-mabora-di-singaraja-bali/, accessed on February 6, 2018).

Table 1

The content of alcohol, ethanol and flavor produced from Arak Bali and Rum

\begin{tabular}{|c|l|l|l|}
\hline No & \multicolumn{1}{|c|}{ Content } & \multicolumn{1}{|c|}{ Arak Bali } & \multicolumn{1}{c|}{ Rum } \\
\hline 1 & Taste & $\begin{array}{l}\text { Normal smell and taste and } \\
\text { typical alcoholic drinks }\end{array}$ & $\begin{array}{l}\text { Normal smell and taste and } \\
\text { typical alcoholic drinks }\end{array}$ \\
\hline 2 & $\begin{array}{l}\text { Etanol/alcohol } \\
\left(\mathrm{CH}_{3} \mathrm{CH}_{2} \mathrm{OH}\right)\end{array}$ & Grade of etanol/alcohol $40 \% \mathrm{v} / \mathrm{v}$ & Grade etanol/alcohol $40 \% \mathrm{v} / \mathrm{v}$ \\
\hline 3 & $\begin{array}{l}\text { Metanol } \\
\left(\mathrm{CH}_{3} \mathrm{OH}\right)\end{array}$ & $\begin{array}{l}\text { Grade of metanol no more than } \\
0,01 \% \mathrm{v} / \mathrm{v} ;\end{array}$ & $\begin{array}{l}\text { Grade of metanol no more than } \\
0,01 \% \mathrm{v} / \mathrm{v}\end{array}$ \\
\hline
\end{tabular}

Source : Anom.D 2009

Based on table 1 that has been described, Balinese Arak has the same dominant taste as Rum and each has the same level of methanol and ethanol. Ethanol is also called ethyl alcohol which is a kind of volatile, flammable, and colorless beverage. Ethanol is the type of alcohol referred to in alcoholic beverages circulating in the community (Sunarya and Setiabudi, 2015). Methanol or methyl alcohol is the simplest form of alcohol, Methanol is made on a large scale through distillation of hard wood producing about 225 gallons of dicylate containing 6\% Methanol, in the form of clear liquid and distinctive smell (Darmono, 2009).

From the explanation above, it is known that the content of Methanol, Ethanol and flavors of Arak Bali is almost the same as Light Rum For this reason, it is necessary to experiment with making mojito mixed drinks using Arak Bali as an ingredient for Light Rum and expected Mojito mixed drinks using Arak Bali to be superior compared to using Light Rum.

The development of mixed drinks made from Arak Bali will provide a new nuance in the food and beverage industry. So based on the preliminary data it is necessary to find out the rating of tourists on the quality of the Arak Bali-based mojito in Kuta Bali in terms of taste, namely Taste of cocktail, Flavor of
In the Kuta tourism area there are many business bars that sell mojito. According to the Bali Provincial Tourism Office in 2017 there are 98 business bars in the Kuta tourism area. From the results of the initial survey, there were 7 bar businesses selling mojito made from Balinese wine. The following data from the 7 Bar businesses as in table 2:

Table 2

Bar that sells Mojito made from Arak Bali in Kuta, Bali

\begin{tabular}{|c|l|l|}
\hline No & \multicolumn{1}{|c|}{ Nama } & \multicolumn{1}{|c|}{ Alamat } \\
\hline 1 & Tequila Bar & Jl. Pantai Kuta Bali \\
\hline 2 & Su's Bar & $\begin{array}{l}\text { Jl. Benesari 29, Kuta } \\
\text { Bali }\end{array}$ \\
\hline 3 & Apache Bar & Jl. Legian Kuta, Bali \\
\hline 4 & $\begin{array}{l}\text { Eikon Bar \& } \\
\text { Club }\end{array}$ & Jl. Legian Kuta, Bali \\
\hline 5 & My Konos & Jl. Laksmana 52, Kuta \\
\hline 6 & $\begin{array}{l}\text { Cube Bar } \\
\text { Jl. Batu Bolong No 55, } \\
\text { Kuta }\end{array}$ \\
\hline 7 & $\begin{array}{l}\text { Doom } \\
\text { Kitchen \& } \\
\text { Bar }\end{array}$ & $\begin{array}{l}\text { Jl. Raya Canggu No 1, } \\
\text { Kuta }\end{array}$ \\
\hline
\end{tabular}

cocktail, Texture of Cocktail, Color of Cocktail, Standard Glassware and Standard Drink Size. To further develop the potential of Arak Bali as a mixed drink ingredient and to bring out one of Bali's uniqueness, especially in the field of beverages, so that local genius Bali has an active role in the era of 
globalization and to improve the economic conditions of the Balinese people.

\section{LITERATURE REVIEW}

The journal entitled "BEVQUAL: a tool for measuring the performance of quality in beverage operations" by Bujisic, M. et al (2018) examines the quality of service of beverage products in the Bar business. This study uses a quantitative method with exploratory factor analysis by interviewing Bar Managers and customers through focus group discusion (FGD) to make research instruments. The results of the distribution of 6-dimensional questionnaires with 23 indicators on 405 customers give the results of factors that play a good role on customer satisfaction is the factor of atmosphere, service quality, and price while the beverage quality factor and location do not affect customer satisfaction.

Journal with the title "Alcohol Prices, Beverage Quality, and the Demand for Alcohol: Quality Substitution and Price Elasticities" by Gruenewald, P.J et al (2006) examined the relationship between the price of alcoholic beverages, the quality of drinks and the level of sales. The analysis in this study is quantitative analysis using multiple regression. The results of this study indicate that customers respond that prices increase from total consumption and vary from brand to brand. Significant relationship to sales to price increases.

The journal, entitled "The effect of glass on evaluation of beverage thirst quenching quality" by Gueguen, N (2003), examined the effect of glass color on the evaluation of drinks. The purpose of this study is to show the effect of glass color on the impression of drinking satisfaction by customers. Observations were carried out on 20 men and 20 women as panelists in this study. The colors of the glasses that are tested are blue, green, yellow and red. The results of the observations of 40 panelists that the glass in blue gives the best impression in giving the customer satisfaction.

All of the above studies can be a basis for consideration in research on consumer ratings of the quality of Mojito made from Arak Bali at the Bar in Kuta Bali.

\section{THEORY STUDIES}

Drinks are "Is a liquid which is specifically prepared for human consumption. In additional to filling a basic human need, links from part of the culture of human society ". From this opinion can be interpreted, "Drinks are special liquids prepared for human consumption. In addition to meeting basic human needs, drinks are part of the culture of the community. While the notion of mixed drinks is
"The most mixed drinks include non-alcoholic ingredients. This includes cocktails, high ball, tall drinks, frozen drinks, coffee drinks, and almost every other bar product, with the exception of glass of beer or wine from a straight shot of whiskey or brandy.

The quote can be interpreted that "mixed drinks are an alcoholic drink mixed or added in one or more non-alcoholic ingredients. These include cocktails, high balls, tall drinks, frozen drinks, coffee drinks and almost all other bar products with the exception of a glass of wine and a straight shot of whiskey or brandy (Katsigris and Thomas: 2007).

The evaluation of cocktails uses a combination of the theories of Ristiyana, et al (2000) and Katsigris and Thomas (2007). There are 6 product attributes that are good indicators of cocktail and as an evaluation of the cocktail. According to Ristiyana et al (2000) in his journal which states that cocktails have four product attributes, namely taste, aroma, color, texture. The understanding of each product attribute is as follows:

a) The taste in cocktails has an understanding of a chemical reaction from a combination of various beverage ingredients and creates a new feeling that is felt by the tongue

b) Aroma arises from the processing of this aroma cocktail created from cocktail ingredients such as spirit and liqueur which are processed by each ingredient having a different aroma process and method of concocting a cocktail will also determine the results of the aroma that will smell

c) Cocktail texture is the result or final appearance of the drink including the display color and taste of the drink itself

d) Color is the color that arises after the drink is mixed.

Whereas according to Katsigris and Thomas (2007) mentions that can determine consumers' assessment of cocktails, namely:

a) Standard Glassware is the size of the glass and its shape, each time a drink is made the size of a glass is very important because of the size of the glass we can control the quantity of the ingredients used and the taste of the cocktail itself

b) Standard Drink Size is the size of a drink that refers to the amount of the main ingredient used per drink made. In each bar the standard drink size most have different standard drinks, especially drinks whose main ingredients are spirit.

Mojito according to Katsigris and Thomas (2007) are:

"The key into refreshing Cuban cocktail is the fresh mint and fresh limes, muddled together in the bottom 
of a Collins glass. (the mojito of yesteryear was made with rum, sugar cane, and yerba buena, and indigenous, minty herb). Muddling mint and lime extracts the lime juice without the zest and liberates the fresh smell and flavor of the mint. Simple syrup is added; the glass is filled with cube ice and a liberal pour of light rum, then finished with club soda and topped with a mint spring or a stick of fresh sugar cane. A properly made mojito balances both sweet and tangy flavors.

Mojito is included in a tropical drink originating from Havana, Cuba is usually made from five ingredients Light rum, Sugar, Lime, Soda water, and Mint Leaf are intended to cover the rum's effects that are hard, with this drink very popular as a summer drink in the world west.

The recipe for making Mojito with rum is 6 pcs ice cubes, $1 \frac{1}{2} 2$ oz light rum, $1 / 2$ oz lime juice, $\mathrm{z}$ oz simple syrup, 10 mint leaf, top with soda water. The recipe for making Mojito with Arak Bali is 6 pcs ice cubed, 11/2 oz Arak Bali, 1/2 oz lime juice, z oz simple syrup, 10 mint leaf, top with soda water.

\section{RESEARCH METHODS}

This research was conducted at 7 bar businesses located in Kuta Bali that sell Mojito made from Arak Bali with a total of 30 respondents. Research on Tourist Evaluation of Arak Bali-Based Mojito is a simple quantitative descriptive study, namely problem solving techniques by systematically collecting data using a mean which is the sum of all data divided by the amount of data described in a language that is easy to understand and compare with reality faced in the field with existing theories, so that in the end they can draw conclusions by giving logical reasons.

The work steps used to analyze the data are as follows:

1) Distributing questionnaires to respondents in this case are consumers of bars who have enjoyed mojito made from Balinese wine. Making a questionnaire with a Likert scale approach. Likert scale is used to measure attitudes, opinions and perceptions of a person or group of people towards social phenomena (Sugiono, 2013: 86). The fivelevel scale (likert) is used to give weight to the respondent's answer. It is intended that the data obtained from the results of questionnaires in the form of qualitative data can be quantified so as to facilitate calculations. Each answer to the questionnaire has a weight or score score with a Likert scale that is a very good answer value 5, the answer is good the value is 4 , the answer is good enough the value is
3 , the answer is not good value 2 and the answer is not good the value is 1 .

2) Collecting questionnaires, questionnaire data that has been filled in by tourists is then collected.

3) Tabulate the results of the questionnaire, the answers that have been collected are then entered into the table making it easier to find the mean.

4) Looking for the mean value, to analyze the frequency of occurrence of all events based on the scale of research the formula used based on the theory of Sudarmayanti and Syarifudin (2002: 182) is:

Mean $=\sum(\mathrm{F} 1 \times 1+\mathrm{F} 2 \times 2+\mathrm{F} 3 \times 3+\mathrm{F} 4 \times 4+\mathrm{F} 5 \times 5)$

$\mathrm{F} 1+\mathrm{F} 2+\mathrm{F} 3+\mathrm{F} 4+\mathrm{F} 5$

Note :

$\mathrm{F} 1 \times 1$ is the number of results of the middle value at times with frequency

$\mathrm{F} 1$ is the number of frequency

5) Enter the mean value into the interval class, to obtain quantitative data through the questionnaire the value of each statement is calculated by multiplying the entire frequency of data by weight, the product of the multiplication divided by the number of respondents who have completed the complete questionnaire. The calculation is done by clarifying the score according to the class interval, as follows:

a. Number of Classifications $(\mathrm{K})=5$ classes

b. Range $(\mathrm{R})=$ Highest value - lowest value $=5-1=4$

c. The length of the interval class is calculated by the formula:

$$
\begin{aligned}
& C=R: K \\
& =4: 5=0.8
\end{aligned}
$$

Information:

$\mathrm{R}=$ Range

$\mathrm{K}=$ Number of classifications

$\mathrm{C}=$ Class interval distance

From the above calculations, the class intervals are as follows:

1. Very Bad, which is in the interval of 1.00 to $<1.80$

2. Not Good, ie at intervals of 1.80 to $<2.60$

3 . Enough, which is at intervals of 2.60 to $<3.40$

4. Good, that is in the interval of 3.40 to $<4.20$

5. Very good, which is at intervals from 4.20 to 5.00 
6) Analyzing the indicators of mojito made from bali wine can be tested with Taste of cocktail, Flavor of cocktail, Texture of Cocktail, Color of Cocktail, Standard Glassware and Standard Drink Size.

\section{DISCUSSION}

By distributing 40 questionnaires and 30 complete ones or 75 percent of the questionnaires distributed. The following is a recapitulation of the results of the questionnaire on Balinese mojito in 7 bar businesses in Kuta Bali that were distributed during May 2018.

Characteristics of Respondents

Characteristics of 30 respondents who have visited and enjoyed Balinese mojito based on 7 bar businesses in Kuta based on sex as much as $56.67 \%$ are male and $43.33 \%$ female, so it can be assumed that the majority of tourists who enjoy mojio are made from the base of bali wine is male. Based on the country of origin it can be seen that the majority of respondents came from Australia as much as 50 percent, then from Indonesia as much as 30 percent, Japan as much as 15 percent and Europe as much as 5 percent.

Data Analysis

Based on the results of the calculation of questionnaire data and guided by the quality indicators of mojito made from Balinese wine. Here are the results of the rating of tourists on the mojito made from bali wine at 7 bar businesses in Kuta.

Table 3

Average Questionnaire for Assessment of Mojito Made from Arak Bali in Kuta Bali

\begin{tabular}{|c|c|c|c|c|c|c|c|}
\hline $\begin{array}{l}\text { Indicator } \\
\text { Respondent }\end{array}$ & $\begin{array}{l}\text { Taste of } \\
\text { Cocktail }\end{array}$ & $\begin{array}{l}\text { Flavour of } \\
\text { Cocktail }\end{array}$ & \begin{tabular}{|l} 
Texture of \\
Cocktail \\
\end{tabular} & $\begin{array}{l}\text { Colour of } \\
\text { Cocktail } \\
\end{array}$ & \begin{tabular}{|l} 
Standard \\
Drink Size \\
\end{tabular} & $\begin{array}{l}\text { Standard } \\
\text { Glassware }\end{array}$ & $\begin{array}{l}\text { Clasification } \\
\text { Interval }\end{array}$ \\
\hline 1 & 5 & 5 & 3 & 3 & 5 & 4 & 4.10 \\
\hline 2 & 5 & 4 & 4 & 3 & 4 & 5 & 4.10 \\
\hline 3 & 4 & 3 & 3 & 4 & 4 & 4 & 3.60 \\
\hline 4 & 4 & 4 & 2 & 4 & 4 & 2 & 3.30 \\
\hline 5 & 4 & 4 & 4 & 4 & 4 & 3 & 3.80 \\
\hline 6 & 5 & 4 & 3 & 3 & 5 & 4 & 4.00 \\
\hline 7 & 3 & 3 & 2 & 2 & 4 & 3 & 2.80 \\
\hline 8 & 4 & 4 & 3 & 2 & 4 & 4 & 3.50 \\
\hline 9 & 4 & 3 & 4 & 4 & 4 & 2 & 3.50 \\
\hline 10 & 5 & 3 & 4 & 4 & 5 & 3 & 4.00 \\
\hline 11 & 5 & 4 & 3 & 5 & 3 & 2 & 3.60 \\
\hline 12 & 4 & 4 & 2 & 3 & 4 & 4 & 3.50 \\
\hline 13 & 4 & 4 & 3 & 4 & 3 & 4 & 3.60 \\
\hline 14 & 5 & 3 & 4 & 3 & 5 & 3 & 3.80 \\
\hline 15 & 4 & 4 & 2 & 3 & 4 & 2 & 3.10 \\
\hline 16 & 5 & 3 & 4 & 2 & 5 & 3 & 3.60 \\
\hline 17 & 3 & 4 & 3 & 4 & 2 & 2 & 3.00 \\
\hline 18 & 5 & 4 & 5 & 4 & 4 & 5 & 4.50 \\
\hline 19 & 5 & 3 & 3 & 3 & 5 & 2 & 3.50 \\
\hline 20 & 5 & 4 & 3 & 4 & 5 & 3 & 4.00 \\
\hline 21 & 4 & 2 & 3 & 4 & 4 & 4 & 3.50 \\
\hline 22 & 5 & 3 & 3 & 2 & 4 & 3 & 3.30 \\
\hline 23 & 3 & 3 & 2 & 3 & 4 & 2 & 2.80 \\
\hline 24 & 5 & 4 & 3 & 4 & 5 & 5 & 4.30 \\
\hline 25 & 4 & 3 & 3 & 3 & 4 & 4 & 3.50 \\
\hline 26 & 4 & 2 & 4 & 2 & 4 & 2 & 3.00 \\
\hline 27 & 4 & 3 & 4 & 4 & 4 & 3 & 3.60 \\
\hline 28 & 4 & 2 & 4 & 2 & 5 & 3 & 3.60 \\
\hline 29 & 4 & 4 & 3 & 4 & 5 & 4 & 4.00 \\
\hline 30 & 5 & 4 & 3 & 4 & 5 & 4 & 4.10 \\
\hline Total & 130 & 104 & 96 & 100 & 127 & 98 & 108.6 \\
\hline Average & 4.30 & 3.50 & 3.20 & 3.30 & 4.20 & 3.30 & 3.62 \\
\hline Category & Good & Good & Enough & Enough & Good & Enough & Good \\
\hline
\end{tabular}


From the calculation of the above average, the average value of mojito made from bali wine in Kuta Bali is categorized according to the specified interval class.

The following is table 4 which describes the category of rating of tourists on mojito made from Balinese wine in Kuta Bali.

Table 4

Recapitulation of Tourist Appraisal of Indicators Rating of Mojito Made from Arak Bali in Kuta Bali

\begin{tabular}{|l|l|l|}
\hline $\begin{array}{l}\text { Assesment } \\
\text { Indicator }\end{array}$ & Average & Category \\
\hline Taste Of Cocktail & 4.30 & Good \\
\hline $\begin{array}{l}\text { Flavour Of } \\
\text { Cocktail }\end{array}$ & 3.50 & Good \\
\hline $\begin{array}{l}\text { Texture Of } \\
\text { Cocktail }\end{array}$ & 3.20 & Enough \\
\hline $\begin{array}{l}\text { Colour Of } \\
\text { Cocktail }\end{array}$ & 3.30 & Enough \\
\hline $\begin{array}{l}\text { Standard Drink } \\
\text { Size }\end{array}$ & 4.20 & Good \\
\hline $\begin{array}{l}\text { Standard } \\
\text { Glassware }\end{array}$ & 3.30 & Enough \\
\hline Overall Average & 3.62 & Good \\
\hline
\end{tabular}

From table 4 above, it can be seen that rating of tourists on bali-based mojito seen from 6 taste of cocktail indicators get an average score of 4.30 including Good category, flavor of cocktail gets an average value of 3.50 including category Good, texture of cocktail gets value on average 3.20 including the Enough category, color of cocktail gets an average score of 3.30 including the Enough category, the standard drink size gets an average score of 4.20 including the Good category and for the standard glassware indicator the average value is 3.30 including the sufficient category.

Overall, the rating of tourists on the quality of mojito drinks made from bali wine in the bar business in Kuta Bali is in a good category with a value of 3.62 with this result, the quality of the balinese-based mojito is sufficient. Although of the 6 indicators there are still 3 indicators that get sufficient ratings, namely on the texture of cocktail indicator, color of cocktail and standard glassware that must be improved to be good.

\section{CONCLUSION}

Based on the analysis of the data conveyed in the discussion, it can be concluded that the overall rating of tourists on Balinese Mojito is good with a value of 3.62. From the 6 assessment indicators, there are 3 good categories, namely the indicator of Taste of Cocktail, Flavor of Cocktail and Standard Drink Size, while the 3 indicators of Texture of Cocktail, Color Of Cocktail and Standard Glass Ware get enough ratings. Indicators that get enough assessment must be improved to be good by continuing to train the bartenders to develop themselves and producers of Arak more able to improve the quality of their Arak. Beside that the mojito based on Arak Bali that sold at bars on Kuta Bali must be promoted more to the tourist. So that local Balinese geniuses have an active role in the era of globalization and to improve the economic conditions of local communities and able to bring out one of the uniqueness of Bali.

\section{REFERENCES}

Anom.D, 2009. Production Process and Characteristics of Arak in Sidemen District, Karangasem Regency, Bali. Atmojo, M.w. (2004). Bars, Beverages and Services. Yogyakarta: Andi.

A. Permatasari, 2014. Enzimatic Making Of Cirup Path Glucose.

Ferry Ferdiansyah. 2007. Content And Activities Of Physiotherapy Pharmacology (Citrus Aurantifolias) journal.unpad.ac.id/farmaka/article/download/12964/pdf.

Accessed on July 17, 2018

NR Fajriaty (2016: 2) differences in E. colipada bacterial contamination of ice cubes using PDAM and non PDAM water raw materials.

eprints.ums.ac.id/43025/16/BAB\%20I.pdf. Accessed on July 17, 2019

Jellinek, 1985. Understanding organoleptics. Jakarta: Gramedia Library.

https://www.internationalbeveragenetwork.com/26648/Gw an Gwan HOO. Accessed on July 16, 2018.

https://indonesia.tripcanvas.co/id/Bali/bar-tempat0hiburanmalam/, accessed on February 6, 2018

http: // yangkosongadako. Blogspot .co. id / 2011/10 / bacardi. html, accessed on February 6, 2018 https://aditaroepratjeka.wordpress.com/2011/06/03/ora-etmabora-di-singaraja-bali/, accessed on February 6, 2018 Katsigris, 2007. The Bar And Baverage Book. New Jersey: Jhn Wiley \& Sons, inc.

Likert, R. (1967), New Patterns of Management, Mc GrawHill Book Company, New York.

Lumnauw, F. (2000). Bar and Drink. Jakarta: PT. Gramedia Main Library.

Mardalis. 2008. Research Methods A Proposal Approach. Jakarta: Bumi Aksara 